\title{
RANCANG BANGUN APLIKASI SISTEM INFORMASI PENJUALAN POMPA DAN VAKUM BLOWER PADA PT. MANDALA TEKNIK JAKARTA
}

\author{
Nur Azizah ${ }^{1}$ \\ Bayu Pramono ${ }^{2}$ \\ Aditya Pratama ${ }^{3}$ \\ Dosen STMIK Raharja ${ }^{1,2}$ \\ STMIK Raharja Jurusan Sistem Informasi ${ }^{3}$ \\ Jl. Jendral Sudirman No. 40, Modern Cikokol-Tangerang \\ e-mail:nur.azizah@raharja.info, bayupramono@raharja.info,pratama.aditya81@gmail.com
}

\begin{abstract}
ABSTRAK
Proses kalkulasi penjualan pada PT. MANDALA TEKNIK sampai saat ini meskipun telah menggunakan komputer namun masih belum terintegrasi karena proses penyusunan kalkulasi hitung barang dilakukan secara terpisah dengan proses pengamatan kurva. Proses kalkulasi penjualan ini masih belum memberikan hasil maksimal karena informasi tentang data penjualan dan pengamatan grafik yang belum terstruktur dengan baik sehingga menyulitkan proses penghitungan kalkulasi penjualan dan membutuhkan waktu penginputan yang lama. Maka dari itu penulis berusaha untuk menganalisa permasalahan yang ada pada sistem penjualan tersebut dan mencari solusi dari permasalahan yang ada. Metode penelitian yang penulis lakukan adalah metode Sistem Development Life Cycle (SDLC), dan prototype untuk mendeskripsikan model sistem usulan. Dengan dihasilkannya sebuah penelitian sistem kalkulasi penjualan ini dapat dijadikan dasar perbaikan sistem yang bertujuan untuk memaksimalkan pekerjaan. Disarankan bahwa perlu diterapkannya sistem yang dapat membantu mempersingkat waktu pengolahan data kalkulasi penjualan, mengatasi masalah human error dan menghasilkan laporan-laporan yang cepat dan akurat.
\end{abstract}

Kata Kunci : Pompa Vakum Blower, Sistem Informasi Penjualan, PT. Mandala Teknik Jakarta

\begin{abstract}
The process of calculation of sales at PT. MANDALA TEKNIK until today although it has been used a computer but still have not been integrated because the process of preparing the goods arithmetic calculation is carried out separately by the observation process curve. Sales calculation process is still not give the maximum output for information on the sales data and observation charts that have not been structured properly so that complicate the process of counting the calculation of sales and require inputting a long time. Thus the authors attempted to analyze the existing problems in the sales sistem and seek solutions to existing problems. The research method that writers do is a method of System Development Life Cycle (SDLC), and protoryping to describe models future sistem. With the conclusion of a study of sales calculation system can be used as the basis of system improvements that aim to maximize employment. It is suggested that the necessary implementation of the sistem that can help shorten the sales data processing calculations, solve the problem of human error and generate reports quickly and accurately.
\end{abstract}

Keyword : Vacuum Pump Blower, Sales Information Sistem, PT. Mandala Technic Jakarta 


\section{PENDAHULUAN}

Teknologi adalah ilmu pengetahuan terapan atau dapat pula diterjemahkan sebagai keseluruhan sarana untuk menyediakan barang barang yang diperlukan bagi kelangsungan dan kenyamanan hidup manusia. Seiring dengan kemajuan teknologi diberbagai bidang, terutama dibidang penjualan seakan akan tidak ada matinya untuk mempelajarinya. Dari hari kehari kemajuan teknologi di bidang penjualan yang terus berkembang salah satunya adalah komputerisasi di bidang penjualan.

Komputer merupakan sarana untuk menyelesaikan pekerjaan dengan cepat dan tepat, aplikasi komputer dibidang penjualan salah satunya adalah sistem penjualan.

Dari berbagai perkembangan teknologi informasi tersebut, salah satu perkembangan yang telah pesat berkembang diantaranya teknologi informasi dalam bidang pengolahan data. Tetapi, dari sekian banyaknya perkembangan teknologi informasi, masih ada sebagian kalangan masyarakat yang belum sepenuhnya dapat menikmati perkembangan dari teknologi informasi tersebut, kita ambil contoh adalah para karyawan PT. Mandala Teknik. Para karyawan masih menggunakan kertas dalam melihat kurva pompa untuk mengambil keputusan bahwa barang tersebutlah yang sangat tepat untuk customer dengan menginputkan data ke komputer setiap data penjualan barang.

Dari kajian tersebut, maka dikembangkan sebuah aplikasi pengolahan data dalam bentuk sistem informasi untuk penjualan pompa dan vakum blower berbasis desktop. Diharapkan sistem informasi yang akan dibuat ini akan dapat membantu para karyawan dalam pengisian data barang dan dapat membantu dalam penghitungan kalkulasi penjualan secara cepat dan efisien dan dapat membantu mengurangi human error. Aplikasi ini dibangun dengan menggunakan bahasa pemrograman Microsoft Visual Studio .Net 2008 dan menggunakan SQL Server sebagai aplikasi pendukung basis data.

Permasalahan yang saat ini dihadapai oleh PT. Mandala Teknik adalah lamanya pemberian harga dan curva barang terbaik kepada customer, sering terjadinya human error terkhusus kepada karyawan baru, tidak adanya sistem yang memantau kinerja karyawan dalam melakukan penjualan untuk mencaai target perusahaan.

Penelitian yang dilakukan dengan studi kasus pada PT. Mandala Teknik memiliki beberapa aspek yang harus kita lakukan dalam penginputan dan pemberian kualitas barang dan harga terbaik terhadap customer. Setelah diperoleh hasil perhitungan kalkulasi penjualan.

\section{RUMUSAN MASALAH}

Sesuai dengan pembahasan penelitian yang telah diuraikan pada sebelumnya, penelitian ini secara jelas berkaitan dengan Rancang Bangun Sistem Informasi Penjualan Pompa Dan Vakum Blower Pada PT. Mandala Teknik Jakarta.

Maka dari penjelasan rumusan masalah tersebut, dapat ditarik beberapa permasalahan sebagai berikut :

1. Bagaimana alur sistem penjualan yang dilakukan perusahaan terhadap customer yang berjalan saat ini? 
2. Bagaimana pemantauan kinerja karyawan yang dilakukan oleh perusahaan saat ini?

3. Bagaimana perancangan sistem yang akan digunakan sebagai pengganti atau software penghitung penjualan pada PT. Mandala Teknik?

\section{METODELOGI PENELITIAN}

Metode System Development Life Cycle (SDLC/Siklus Hidup Pengembangan Sistem) atau Sistems Life Cycle (Siklus Hidup Sistem), dalam rekayasa sistem dan rekayasa perangkat lunak, adalah proses pembuatan dan pengubahan sistem serta model dan metodologi yang digunakan untuk mengembangkan sistem-sistem tersebut.

Konsep ini umumnya merujuk pada sistem komputer atau informasi. SDLC juga merupakan pola yang diambil untuk mengembangkan sistem perangkat lunak, yang terdiri dari tahap-tahap: rencana (planning), analisis (analysis), desain (design), implementasi (implementation), uji coba (testing) dan pengelolaan (maintenance) (Blanchard, B. S., \& Fabrycky, W. J.(2006).

Dalam rekayasa perangkat lunak, konsep SDLC mendasari berbagai jenis metodologi pengembangan perangkat lunak. Metodologi-metodologi ini membentuk suatu kerangka kerja untuk perencanaan dan pengendalian pembuatan sistem informasi, yaitu proses pengembangan perangkat lunak. Terdapat 3 jenis metode siklus hidup sistem yang paling banyak digunakan, yakni: siklus hidup sistem tradisional (traditional sistem life cycle), siklus hidup menggunakan protoyping (life cycle using prototyping), dan siklus hidup sistem orientasi objek (object-oriented sistem life cycle).

\subsection{Tahapan SDLC}

SDLC terdiri dari beberapa tahapan-tahapan berdasarkan analisa kebutuhan yang ada.

Dimulai dari analisa kebutuhan perangkat lunak akan dibuat terlebih dahulu desain dari kebutuhan tersebut untuk mempermudah dalam pengerjaannya. Kemudian segala kebutuhan tersebut di implementasikan dengan dua tahap yaitu tahap analisa dan tahap evaluasi (User Acceptance Test). Setelah melakukan implementasi, maka proses tersebut akan dikembalikan kembali ke dalam tahap desain untuk pengembangan kembali perangkat lunak ke versi yang terbaru.

\subsection{Proses Tahapan SDLC}

\section{Analisa sistem (sistem analysis)}

a. Studi pendahuluan

Merupakan studi yang dilakukan untuk mempertajam arah studi utama. Dengan demikian,studi pendahuluan bisa saja menghasilkan perubahan prosedur penmelitian, meningkatkan pengukuran, meningkatkan peningkatkan kepercayaan asumsi,dan desain yang lebih mantap.

Studi pendahuluan merupakan salah satu aktivitas atau kegiatan persiapan yang dilakukan oleh seorang peneliti, dengan tujuan untuk menentukan objek dan subjek penelitian yang tepat, yang sesuai dengan tema penelitian yang menjadi fokus kajian peneliti. 


\section{b.Studi kelayakan}

Setelah studi pendahuluan dilakukan, langkah berikutnya yang diperlukan oleh analisis sistem adalah melakukan studi kelayakan (feasibility study).

Studi kelayakan (feasibility study) terdiri dari lima macam kelayakan yang disebut dengan TELOS, yaitu
a) Studi kelayakan Teknologi
b) Studi kelayakan Ekonomis
c) Studi kelayakan Legal
d) Studi kelayakan Operasi
e) Studi kelayakan Sosial

c.Mengidentifikasi permasalahan dan kebutuhan pemakai

d.Memahami sistem yang ada.

e.Menganalisa hasil penelitian.

\section{Perancangan sistem (system design)}

Tahap berikut dari SDLC setelah tahap analisis sistem adalah tahap perancangan sistem (sistem design). Tahap perancangan sistem mempunyai dua tujuan utama yaitu

a) Memberikan gambaran secara umum tentang kebutuhan informasi kepada pemakai sistem secara logika.

b) Memberikan gambaran yang jelas dan rancangan bangunan yang lengkap kepada pemrograman computer dan ahli-ahli teknik lainya.

Tujuan perancangan sistem :

a. Perancangan sistem secara logika (logical sistem design) atau perancangan sistem secara umum (general system design)

b. Perancangan sistem secara terinci (detail sistem design)

Siklus atau daur hidup pengembangan sistem tampak jika sistem yang sudah dikembangkan dan dioperasikan tidak dapat dirawat lagi,sehinggadibutuhkan pengembangan sistem kembali yang tampak digambar seperti berikut.

Siklus dan daur hidup pengembangan sistem tampak jika sistem yang sudah dikembangkan dan dioperasikan tidak dapat dirawat lagi, sehingga dibutuhkan pengembangan sistem kembali yang nampak di gambar berikut ini : 


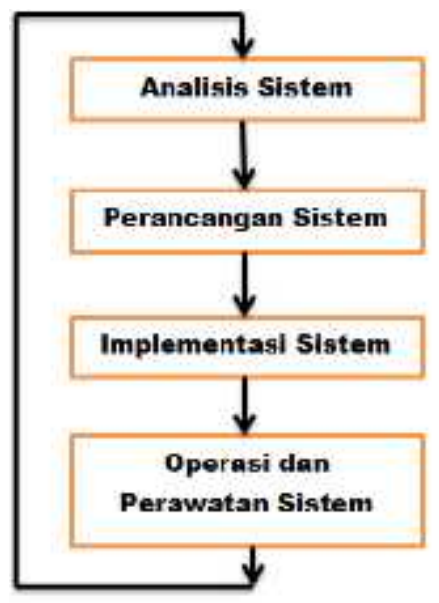

\section{Gambar 1 Siklus hidup pengembangan sistem}

3. Implementasi sistem

Implementasi sistem (sistem implementation) adalah tahap meletakkan sistem supaya siap dioperasikan.

Tahap implementasi sistem terdiri dari beberapa kegiatan sebagai berikut :

1. Mempersiapkan rencana implementasi

2. Melakukan kegiatan implementasi

3. Melakukan konversi sistem.

Implementasi sistem juga merupakan proses mengganti atau meninggalkan sistem yang lama dengan sistem yang baru.

Pendekatan atau strategi konversi yang ada adalah sebagai berikut:

a. Konversi paralel.

Pendekatan atau strategi konversi paralel (parallel conversion dilakukan dengan mengoperasikan sistem yang baru bersama-sama dengan sistem yang lama selama satu periode waktu tertentu.

b. Konversi pilot.

Pendekatan atau strategi konversi pilot (pilot conversion) atau pendekatan konversi lokasi (location conversion) dilakukan bertahap pada suatu lokasi sebagai suatu percontohan dan jika berhasil dilanjutkan ke lokasi yang lainnya

c. Konversi bertahap.

Pendekatan atau strategi konversi bertahap (phasing conversion atau stepped conversion atau staged conversion atau phase-in conversion atau 
phased cut- over conversion) dilakukan dengan menerapkan masing-masing modul dari sistem secara bertahap dan urut.

d. Konversi langsung.

Pendekatan atau strategi konversi langsung (direct conversion atau direct cutover atau cold turkey conversion atau abrupt cutover) dilakukan dengan mengganti sistem yang lama langsung dengan sistem yang baru.

\section{Operasi dan Perawatan Sistem}

Setelah sistem diimplementasi dengan berhasil, sistem akan dioperasikan dan dirawat. Tahap ini disebut dengan operasi dan perawatan sistem (sistem operation and maintenance).

\subsection{Kegunaan SDLC}

Adapun kegunaan utama dari SDLC adalah mengakomodasi beberapa kebutuhan. Kebutuhan-kebutuhan itu biasanya berasal dari kebutuhan pengguna akhir dan juga pengadaan perbaikan sejumlah masalah yang terkait dengan pengembangan perangkat lunak. Kesemua itu dirangkum pada proses SDLC yang dapat berupa penambahan fitur baru (baca : kemampuan penggunaan) baik itu secara modular (baca : instalasi parsial atau update dan upgrade perangkat lunak) maupun dengan proses instalasi baru (baca : penggantian perangkat lunak menyeluruh atau software replacement). Dari proses SDLC juga berapa lama umur sebuah perangkat lunak dapat diperkirakan untuk dipergunakan yang dapat diukur atau disesuaikan dengan kebijakan dukungan (baca : software support) dari pengembang perangkat lunak terkait.

\section{KAJIAN LITERATURE}

Literature adalah kesusasteraan atau kepustakaan, sedangkan review adalah suatu tindakan meninjau, memeriksa kembali suatu hal yang telah dikerjakan sebelumnya. Sehingga dalam literature review dapat disimpulkan sebagai Literature review adalah uraian tentang teori, temuan, dan bahan penelitian lainnya yang diperoleh dari bahan acuan untuk dijadikan landasan kegiatan penelitian untuk menyusun kerangka pemikiran yang jelas dari perumusan masalah yang ingin diteliti. Di sumber yang lain mengatakan, literature review adalah analisa berupa kritik (membangun maupun menjatuhkan) dari penelitian yang sedang dilakukan terhadap topik khusus atau pertanyaan terhadap suatu bagian dari keilmuan. Literature review merupakan cerita ilmiah terhadap suatu permasalahan tertentu.

Berikut adalah penelitian yang telah dilakukan dan memiliki korelasi yang searah dengan penelitian yang akan dibahas, antara lain :

\section{a. Penelitian oleh Iyan Gustiana (2009), Universitas Komputer Indonesia,}

Penelitian yang dijalankan oleh Iyan Gustiana yang berjudul "Perancangan Sistem Informasi Penjualan On Line pada PT.Ochikawa Headwears Project" dalam Perancangan Sistem Informasi Penjualan On Line pada PT. Ochikawa Headwears Project. Penelitian ini bertujuan untuk menganalisis sistem penjualan pada PT. Ochikawa Headwears Project. Tujuan penelitian ini adalah untuk untuk menghasilkan suatu sistem penjualan yang menggunakan media web atau internet dalam memasarkan topi jaring 
sehingga transaksi penjualan mudah dilakukan dengan cepat. Berdasarkan hasil penelitian disimpulkan bahwa dapat memberikan kemudahan kepada calon pembeli untuk membeli topi jaring lewat internet. Calon pembeli dapat mengetahui langsung. Untuk mempromosikan atau lebih memperkenalkan perusahaan kepada semua kalangan masyarakat sehingga dapat memperluas jangkauan pemasaran dengan tujuan dapat meningkatkan penjualan. Namun demikian penelitian ini masih membutuhkan adanya sistem yang dapat menjaga keamanan dalam hal transaksi online dan membutuhkan proses backup data secara berkala.

\section{b. Penelitian oleh Ervan Junaidi (2011), STMIK Raharja Cikokol Tangerang,}

Penelitian yang dijalankan oleh Ervan Juaidi yang berjudul "Perancangan Sistem Penjualan Produk pada PT. Natrindo Telepone Seluler Serpong Tangerang". Pada perancangan ini belum dapat menyajikan laporan yang lebih spesifikasi dari tiap proses penjualan produk yang dilakukan.

\section{c. Penelitian oleh Arif Tri Pambudi dan Bambang Sudaryatno, (2015), STMIK AMIKOM Yogyakarta,}

Penelitian yang dijalankan oleh Arif Tri Pambudi dan Bambang Sudaryatno yang berjudul "Sistem Informasi Penjualan (Cash dan Kredit) Mobil Di Sudir Motor Cilacap". Untuk mengatasi permasalahan di atas maka membuat aplikasi program penjualan (Cash dan Kredit) mobil, dengan sistem ini untuk seorang karyawan dapat dengan mudah menyimpan catatan dari data pelanggan, mobil, dan transaksi penjualan terjadi, sementara manajer dapat dengan mudah memeriksa transaksi penjualan melalui laporan bahwa telah ada. Dengan aplikasi ini tingkat kesalahan dapat dikurangi.

Aplikasi ini dibuat dengan menggunakan bahasa pemrograman Visual Basic versi 6.0 sebagai desain antarmuka dan Sql Server 2008 sebagai database-nya.

\section{d. Penelitian oleh M. Lutfi Efendi dan Kusnawi, (2015), STMIK AMIKOM Yogyakarta,}

Penelitian yang dijalankan oleh M. Lutfi Efendi dan Kusnawi yang berjudul "Perancangan Sistem Informasi Penjualan Elektronik Berbasis Dekstop Pada Toko Ceria Shop". Realisasi pengembangan Sistem Informasi Elektronik Penjualan ini adalah aplikasi komputer yang mampu membuat sistem informasi yang dirancang untuk mewakili seluruh aplikasi Sistem Informasi Penjualan mampu mengelola data yang dihasilkan penjualan, yang meliputi transaksi penjualan, data barang, dan menghasilkan laporan yang lengkap, akurat dan selalu aktual untuk setiap tingkat manajemen. Pendekatan sistem yang digunakan dalam sistem informasi ini menggunakan OOP (Object Oriented Programming) Rancangan sistem menggunakan Netbeans Java dan Xampp.

Hasil dari aplikasi Sistem Informasi desain Penjualan menunjukkan bahwa peran aplikasi komputer dalam sistem informasi sangat penting sebagai penunjang dalam meningkatkan kualitas penjualan dan kegiatan pelayanan di lingkungan perusahaan.

\section{e. Penelitian oleh Sugawati, (2014), Universitas Dian Nuswantoro Semarang,}

Penelitian yang dijalankan oleh Sugawati yang berjudul "Sistem Informasi Penjualan Busana Muslim Pada Nuwrhie Nunki Fashion Semarang Berbasis Web". Sistem informasi penjualan ini diharapkan menjadi metode alternatif dalam melakukan promosi dan transaksi pembelian yang lebih mudah, efektif dan efisien. Sistem ini terfokus pada user (pelanggan) dan admin. Fitur yang dapat diakses oleh pelanggan setelah melakukan pendaftaran dan login yaitu melakukan proses pemesanan. 
Perancangan dilakukan menggunakan tool software Xampp dengan web desainer. Macromedia Dreamweaver 8, serta flash untuk animasi. Pembuatan sistem penjualan ini memudahkan pelanggan dalam melakukan proses pembelian serta memudahkan pemilik toko dalam melakukan promosi produknya lebih efektif dan efesien.

Hasil studi pustaka (literature review) ini menjadi alasan untuk melakukan analisa sistem penggajian karyawan pada PT Deka Adhinusa. Dengan membandingkan penelitian ini dengan penelitian-penelitian sebelumnya diatas serta dengan peninjauan yang telah dilakukan dengan matang, sehingga diharapkan akan menghasilkan project yang maksimal dan efektif. Serta sebagai pembuktian bahwa penelitian ini merupakan penelitian yang baru dan berbeda dari penelitian-penelitian yang ada sebelumnya.

\section{HASIL DAN PEMBAHASAN}

Hasil yang dicapai dari penelitian ini adalah aplikasi kalkulasi penjualan pompa dan vakum blower yang berisi sistem penjualan yang terjadi dalam perusahaan. Adapun hasil dari penelitian adalah sebagai berikut :

\section{a. Menu Login}

Menu login merupakan fasilitas untuk masuk ke sistem dengan memasukkan nama dan password. Terdapat dua level yang berbeda dalam fasilitas login, yaitu level administrator dan level user. Ketika memasukkan ID user dan password, sistem akan mengecek user tersebut termasuk dalam level yang mana, yang selanjutnya akan masuk ke halaman sesuai dengan permintaan.

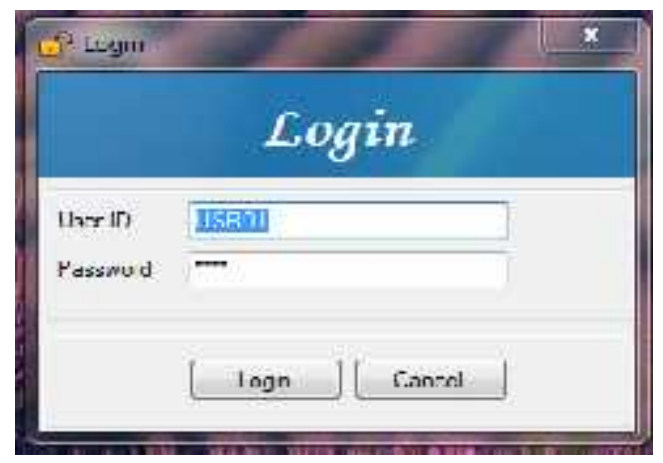

Gambar 2 Menu Login

\section{b. Menu Utama}

Halaman ini terdiri dari beberapa menu diantaranya : Menu File, Master, Pelanggan, Kalkulasi Penjualan, Laporan, Backup Database, Ubah Password, Tentang dan Logout. Tampilan halaman utama dapat dilihat seperti pada gambar

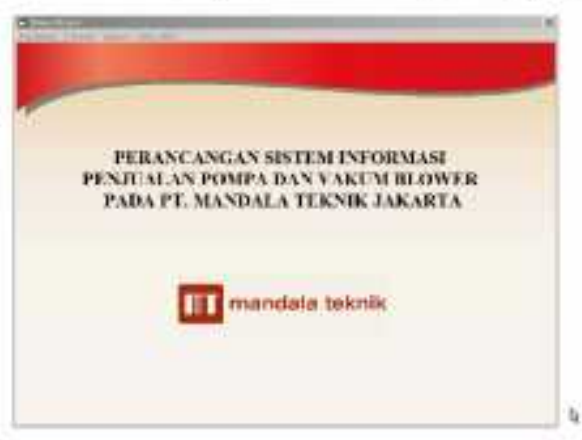

Gambar 3 Halaman Utama 


\section{c. Menu Pelanggan}

Form pelanggan nantinya akan ditampilkan untuk menangani fungsi penambahan/perubahan data pelanggan. Berikut tampilan form pelanggan.

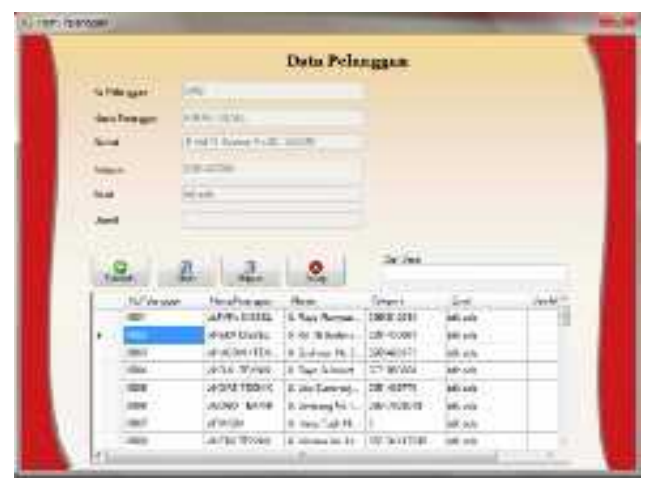

\section{d. Menu Ubah Password}

Gambar 4 Form Pelanggan

Berikut adalah Form Ubah Password yang berfungsi untuk mempermudah user dalam penggantian password aplikasi.

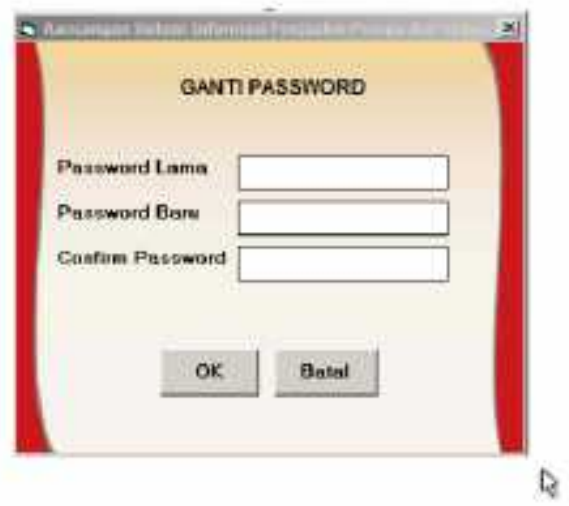

\section{Gambar 5 Menu Ubah Password}

\section{e. Menu Kalkulasi Penjualan}

Pada menu ini semua aktifitas penginputan data penjualan dilakukan, terdapat pilihan filter yang memudahkan user untuk menentukan kurva terbaik yang dapat dilihat oleh user sehingga harga dan kualitas barang yang diberikan kepada customer yaitu pilihan yang terbaik. Berikut interface dari menu kalkulasi penjualan.

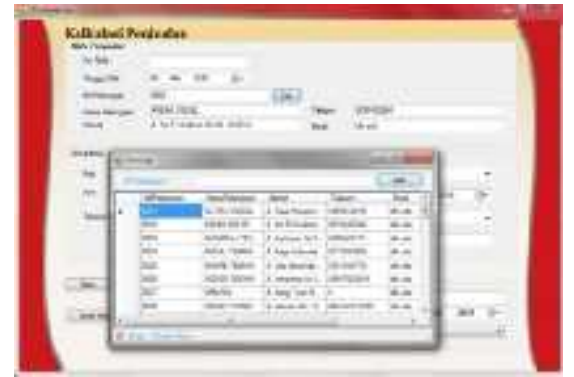

Gambar 6 Kalkulasi Penjualan 1 
Pada menu ini user diminta untuk menentukan menginput customer atau pelanggan terlebih dahulu sebelum melakukan penghitungan penjualan lebih lanjut.

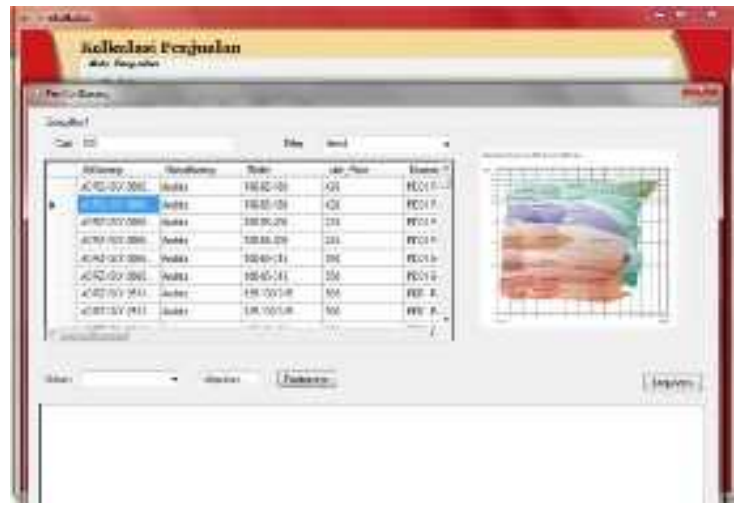

Gambar 7 Kalkulasi Penjualan 2

Pada menu ini user hanya perlu memasukan kategori pencarian pada filter untuk mendapatkan hasil sesuai dengan kebutuhan customer.

\section{f. Backup Database}

Berfungsi untuk membackup database sehingga jika terjadi error pada komputer user data bisa dikembalikan sesuai backup terakhir. Berikut interface menu Backup

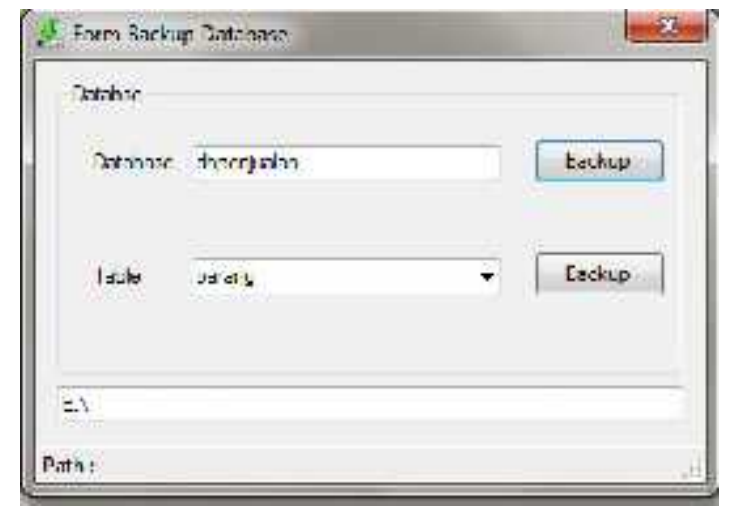

Gambar 8 Backup Database

\section{KESIMPULAN}

Berdasarkan uraian yang telah dibahas pada bab-bab sebelumnya serta hasil pembahasan Aplikasi Sistem Informasi Penjualan Pompa Dan Vakum Blower Pada PT. Mandala Teknik Jakarta, maka dapat ditarik kesimpulan sebagai berikut :

1. Penggunaan sistem manual yang masih digunakan oleh PT. Mandala Teknik digantikan menggunakan sistem aplikasi penjualan berbasis desktop, hal ini bertujuan agar tidak adanya kesalahan penginputan data pada saat melakukan administrasi dalam memberikan harga dan kualitas barang terbaik serta pelayanan penjualan kepada customer dan menjadikan pekerjaan lebih cepat dan tepat.

2. Saat ini kinerja suatu karyawan hanya diisi pribadi karyawan dengan form daily report dan tidak adanya suatu indikasi pemantauan kinerja karyawan dalam 
melakukan penjualan, dengan adanya system penjualan ini maka diharapkan mampu meningkatkan kinerja karyawan dalam melakukan proses penjualan dan mencapai target perusahaan.

3. Dengan adanya sistem informasi penjualan ini customer tidak perlu membutuhkan waktu yang lama untuk mendapatkan harga dan kualitas barang terbaik sehingga karyawanpun dapat menganalisa kebutuhan customer dengan baik dan tidak tertekan limited time

\section{Daftar Pustaka}

[1] Arif Tri Pambudi dan Bambang Sudaryatno, Sistem Informasi Penjualan (Cash dan Kredit) Mobil Di Sudir Motor Cilacap, STMIK AMIKOM Yogyakarta, 2015

[2] Blanchard, B. S., \& Fabrycky, W. J. Sistems engineering and analysis (4th ed.), Prentice Hall, New Jersey, 2006

[3] M. Lutfi Efendi dan Kusnawi, Perancangan Sistem Informasi Penjualan Elektronik Berbasis Dekstop Pada Toko Ceria Shop, STMIK AMIKOM Yogyakarta, 2015

[4] Nurul Anjasari, Pengembangan Sistem Teknologi Informasi Metode SDLC (Sistem Development Life Cycle), Universitas Muria Kudus, 2012 